\title{
Mulçumanos e cristãos em Al Andalus: uma identidade que transcende o corte entre Oriente e Ocidente
}

Carmen Lícia Palazzo ${ }^{1}$

\section{Resumo}

Este artigo analisa aspectos de $\mathrm{Al}$ Andalus, ou seja, da Espanha, no período em que ela esteve em grande parte sob domínio muçulmano, discutindo a questão de sua identidade. Mais do que um encontro de culturas que foram objeto de "tolerância” umas em relação às outras, $\mathrm{Al}$ Andalus se constituiu em uma sociedade única, cujas características não devem ser tratadas como um parêntesis na história do Ocidente, já que é parte integrante do ser hispânico. Ainda que os judeus tenham também participado da formação cultural de Al Andalus, no presente trabalho o enfoque se volta para a relação entre muçulmanos e cristãos, pois envolve questões de exercício de poder político e de objetos públicos da cultura material, aspectos com menor participação do judaísmo sefaradita que, na Península Ibérica, teve atuação mais marcante no campo da filosofia.

Palavras-chave: Al Andalus. Identidade. Hispanomuçulmanos.

\section{Introdução}

A Península Ibérica e o sul da Itália foram palco, no decorrer de grande parte da Idade Média, de um rico encontro de culturas nem sempre desprovido de violência, mas muito fértil no intercâmbio de ideias, de hábitos de vida e também de mercadorias, o que permite questionar uma visão da Europa fechada em si mesma e que só vai abrir seus horizontes a partir do Renascimento.

1 Doutora em História pela Universidade de Brasília. Foi pesquisadora visitante da Georgetown University, em Washington, D.C. e atualmente é pesquisadora convidada e professora na pós-graduação Lato Sensu em História, Sociedade e Cidadania - UniCEUB, e Consultora do Programa de Estudos Judaico-Helenísticos, PEJ/UnB. carmenlicia@yahoo.com. 
Na Idade Média, as viagens, os deslocamentos de vários tipos, eram frequentes no interior da Europa:

Viajar não se constitui, portanto, em uma anomalia na Idade Média. E se o sedentarismo é a regra para muitos camponeses, várias pessoas caminham sem parar por montes e por vales. [...] Todos os heróis de Chrétien de Troyes estão em movimento, pois a viagem lhes traz aventuras, logo, renome. Não partir significa recusar-se a assumir as suas responsabilidades, a ter o seu papel na sociedade, enfim falhar no plano da moral. Em última análise, a rota semeada de provações leva a Deus. Este é o sentido da busca do Santo Graal. $^{2}$ (VERDON, 1998, p. 18-21)

Muitos foram também os viajantes que se aventuraram em direção ao Leste, ao Extremo-Oriente, bem antes que Colombo ou Cabral empreendessem suas expedições. Guilherme de Rubruck, Giovanni Pian del Carpine, Marco Polo e Monte Corvino, entre muitos outros, deixaram relatos importantes de suas viagens, os quais permanecem como fontes valiosas para o entendimento da construção do Oriente no imaginário europeu. É também por meio dos inúmeros relatos de viajantes que se podem desvendar, ao menos em parte, as mentalidades daqueles que os sucederam e que partiram motivados pelas descrições que mostravam um Oriente de grande fascínio.

Cristóvão Colombo e Vasco da Gama eram leitores de Marco Polo, cujo manuscrito:

[...] teve uma repercussão enorme no Ocidente. Primeiro testemunho direto de um mercador e não de um eclesiástico, fazia do mito oriental uma realidade acessível, ao mesmo tempo em que confirmava as riquezas fabulosas do Oriente [...] (BIBLIOTHÈQUE NATIONALE DE FRANCE, 1993, p. 25).

É importante acrescentar, no entanto, que as imagens do Oriente construídas pelos europeus não tiveram origem apenas nas experiências do contato direto dos viajantes. O comércio exerceu um papel importante no relacionamento do

\footnotetext{
2 Todas as traduções de bibliografia em língua estrangeira foram feitas pela autora do artigo.
} 
Ocidente com um Oriente associado frequentemente à ideia de luxo, de extravagância. $\mathrm{O}$ que posteriormente veio a se denominar Rota da Seda constituía-se em uma imensa rede de caminhos, de oásis, de estradas e desvios que, desde a Antiguidade, foram percorridos por mercadores, peregrinos e aventureiros, entre o território chinês e os diversos portos do Mediterrâneo, tais como Istambul, Antioquia e Tiro, chegando também até os portos italianos e à Península Ibérica, onde, desde o século VIII, os muçulmanos eram o poder dominante no que chamavam de $\mathrm{Al}$ Andalus. É possível, em nosso entender, incluir a Espanha, durante o período em que foi governada por muçulmanos, como o extremo mais ocidental da Rota da Seda, em virtude do imenso intercâmbio do qual foi parte ativa (PALAZZO, 2009, p. 464-470).

A rápida afirmação do poder muçulmano na Ásia foi possível principalmente porque o Islã surgiu como uma resposta a inquietações de povos que, submetidos a poderes imperiais despóticos, viam nas palavras de Maomé uma singela mensagem igualitária. Longe de se reportar a textos complexos ou a elaboradas redes de relacionamento, a religiosidade muçulmana tal como a apresentava o Profeta, aproximava os homens de um Deus único que podia ser alcançado mediante a oração e uma vida regrada, sem a necessidade, ao menos nos seus primórdios, da intermediação de uma hierarquia clerical.

Com o passar do tempo, o próprio Islã foi adquirindo contornos diferenciados e os místicos sufistas representaram - e ainda hoje representam - uma rica vertente do encontro entre imaginários distintos que se fundiram, produzindo uma corrente esotérica em uma religião que não parecia permitir tamanho "desvio”. Foram múltiplas as faces do Islã e múltiplas também suas diversas correntes artístico-literárias.

A expansão muçulmana tanto ao longo do que tradicionalmente denomina-se Rota da Seda quanto no norte da África, na Espanha e na Sicília, atesta que era grande a amplitude das influências culturais no rastro da movimentação de mercadores e peregrinos que circularam entre o Oriente e o Ocidente durante a Idade Média. 


\section{0 estabelecimento do Islã na Espanha e o apogeu de Córdoba}

No século VIII, tropas árabes e berberes vindas do Marrocos, mas a mando do califado na Síria, deram início à conquista muçulmana da Península Ibérica, tentadas pelo que se dizia ser um reino visigodo extremamente rico. O primeiro contingente de conquistadores cruzou o Estreito de Gibraltar em 711, estendendo então o domínio islâmico ao Ocidente. Iniciava-se naquele ano o que veio a se constituir em um período de grande desenvolvimento para a Espanha. A população, insatisfeita com a nobreza e com os reis visigodos que exigiam pesados impostos de todos e perseguiam os judeus com violência, recebeu muito bem os muçulmanos que, depois de 711, continuaram a chegar em vários momentos, não apenas como invasores, mas também em correntes migratórias diversas.

Al Andalus, nome dado a toda a região da Península Ibérica que foi governada pelos muçulmanos, prospera. São implantados sistemas de irrigação com canais subterrâneos para que a água não se evaporasse, o que permitia o cultivo de extensos pomares, com frutos diversos. Os conquistadores mandam também construir palácios e residências de luxo utilizando materiais de edifícios visigodos e romanos e adaptando-os ao estilo do que vinha sendo feito no Oriente e no norte da África.

Em 750, quando os Omíadas são derrotados pelos Abássidas no Oriente Médio, ocorre um incidente que terá repercussões em Al Andalus. O jovem Abû'lMutar-rif' Abd-al-Rahmân bin Mu’âwiya, único Omíada que consegue escapar com vida do massacre de sua família, foge para o Marrocos, onde vai viver durante quatro anos, seguindo depois para a Península Ibérica, já que corria a informação de que lá viviam vários simpatizantes da sua dinastia destronada (BARRUCAND; BEDNORZ, 2002, p. 30).

Na Espanha, Abd-al Rahmân terá chance de retomar suas ambições políticas e, em 756, é proclamado emir. Durante seu governo, transplanta para Córdoba o conforto e a exuberância que tinham sido características da corte síria de Damasco, quando sua própria família reinava. Desenvolve durante seu emirado uma relação importante com mercadores que fazem o transporte de produtos de luxo do Oriente e do resto da Europa para a Península Ibérica. 
É Abd-al-Rahmân quem inicia, em 780, a construção da mais bela mesquita da Espanha e um dos grandes marcos da arquitetura islâmica no mundo. Posteriormente, os demais governantes irão ampliá-la tanto para tornar evidente o prestígio da cidade quanto por necessidade de espaço para o número crescente de fiéis. É sempre mantido, no entanto, o plano inicial e o mesmo estilo (ETTINGHAUSEN; GRABAR, 1987, p. 128-134). No entanto:

Cada um dos três grandes governantes da época dos califas fez modificações essenciais na mesquita de Córdoba. O minarete caracteriza a fase de Abd al-Rahmân III; as cúpulas, os arcos lobulados cruzados e os mosaicos bizantinos são próprios da de al-Hakam II; a amplitude da construção adicional caracteriza a de al-Manzûr. A contribuição de cada um deles pode considerar-se como símbolo de sua personalidade e sua concepção de poder. Uma torre é antes de tudo símbolo e emblema de poder e só depois é o lugar do qual os fiéis são chamados para a oração. É um testemunho orgulhoso, visível a longa distância, do poder legítimo do novo califa. ${ }^{3}$ (BARRUCAND; BEDNORZ, 1992, p. 85-86).

Uma profusão de colunas com os arcos inferiores em forma de ferradura, todos em branco e vermelho, causam um enorme impacto. Como é conhecida hoje (ver Figura 1), a mesquita, após todas as ampliações, passou a ter dezenove naves formadas a partir de uma verdadeira floresta de arcos superpostos.

3 Abd-al Rahmân I manteve-se como emir e nunca procurou se tornar Califa, talvez porque os eventos da ascensão dos abássidas e a derrota do Omíadas ainda fosse muito recente no Oriente Médio. O primeiro governante de Córdoba a se intitular Califa foi Abd-al Rahmân III, que mandou construir o minarete na mesquita. O emir é governador de província, no entanto, o califa designa o governante não apenas político, mas espiritual da comunidade islâmica, seu chefe supremo e sucessor do profeta Maomé. 
Figura 1 - Interior da Mesquita de Córdoba ${ }^{4}$

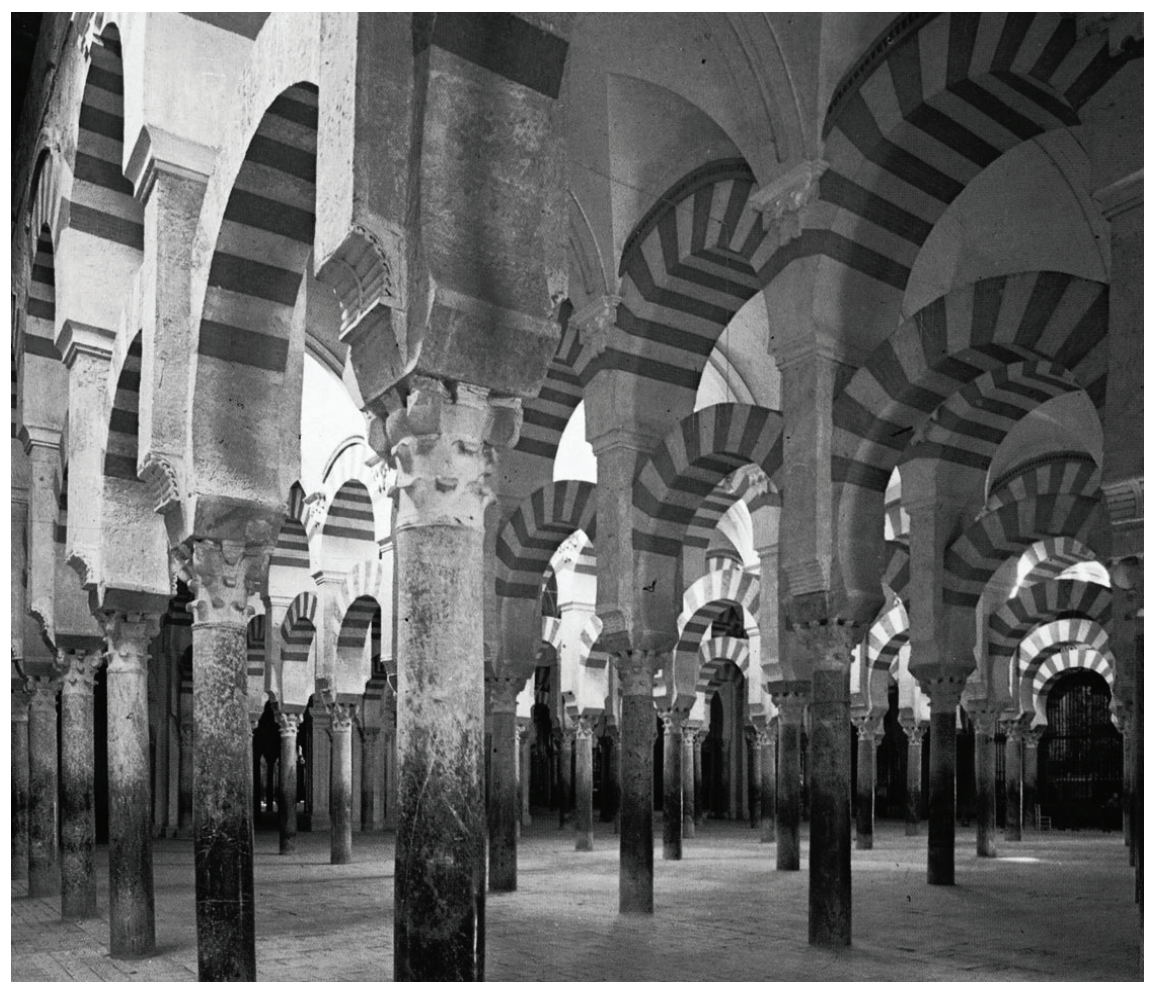

O fato de que muitos dos arcos não se constituem em uma necessidade de sustentação, mas são de efeito puramente decorativo, é uma característica da arquitetura de $\mathrm{Al}$ Andalus. Ao que tudo indica, por meio do uso dos arcos superpostos, os muçulmanos pretendiam evocar os aquedutos romanos como os de Segóvia e de Mérida. Eram obras muito admiradas na época e mantinham-se como o símbolo de um passado no qual o poder imperial havia se estendido até a Península Ibérica.

Para os arcos mais baixos observa-se que foram utilizadas colunas e capitéis de antigas construções romanas e visigóticas, um reaproveitamento que era habitual na Idade Média. Sobre o capitel de cada coluna há uma imposta ${ }^{5}$ a partir

\footnotetext{
4 Foto feita pela autora do artigo.

5 Termo arquitetônico que se refere ao bloco de alvenaria sobre o qual se apoia o arco.
} 
da qual segue um pilar mais grosso que, dessa maneira, prolonga a coluna e serve de apoio aos arcos superiores. Além desta clara influência de Roma na arquitetura muçulmana, outro aporte importante encontrado na mesquita de Córdoba é o uso de mosaicos bizantinos como decoração no mihrab ou nicho que indica a direção das preces. É interessante observar que, embora Bizâncio fosse, até a conquista de Constantinopla, o poder concorrente dos muçulmanos, as relações culturais entre ambos mantiveram-se ativas durante boa parte da Idade Média.

Para a decoração do mihrab, o califa Abd-al-Rahmân III solicitou, diretamente ao imperador de Bizâncio, especialistas em mosaico. O imperador, então, não apenas enviou seus artistas mas também uma razoável quantidade de pedras para a obra. O estilo da decoração realizada é bizantino, mas os motivos são florais e geométricos, já que não eram permitidas figuras humanas em construções religiosas do Islã.

Normalmente os mihrabs são nichos bem decorados mas o de Córdoba destaca-se pela imponência, pela beleza e também pelo fato de se constituir quase em uma pequena sala, mais do que um nicho na parede. O especialista em arte islâmica Oleg Grabar levantou a hipótese de que o mihrab, numa região na qual o rito cristão havia sido muito importante, teria adquirido um sentido litúrgico cerimonial (ETTINGHAUSEN; GRABAR, 1994, p. 137). Caberia, então, perguntar se o objetivo era torná-lo semelhante a uma capela? É interessante lembrar também que em Córdoba foi desenvolvido um ritual considerado único no mundo islâmico - o de levar o Corão em procissão dentro do próprio espaço da mesquita até o nicho de oração.

É evidente que o intercâmbio entre diversas culturas na Espanha muçulmana não se resume à mesquita de Córdoba, mas esse exemplo pontual permite refletir, de maneira mais ampla e para muito além daquela área geográfica, sobre o emaranhado de aportes que, especialmente entre os séculos VIII e XIV, aproximaram de tal maneira o Ocidente e o Oriente que dificilmente seria possível pensar no mundo medieval como separado em duas metades. 


\section{0 desenvolvimento de uma sociedade original}

Como em qualquer cultura, em Al Andalus houve tolerância e intolerância, guerra e paz; mas, com uma enorme diferença em relação a outras partes da Europa: ali florescia uma cultura de aportes religiosos multifacetados, enquanto nas outras partes do continente a fé cristã havia se tornado exclusiva, não aceitando nenhuma manifestação que lhe fosse contrária.

A atração que o Islã e o idioma árabe exerciam sobre as comunidades cristãs, principalmente entre os jovens, era grande e crescia na mesma medida em que Al Andalus prosperava. Foram muito frequentes as conversões voluntárias de cristãos, não apenas por razões de ordem prática, para evitar o pagamento do imposto que era cobrado das comunidades ditas "protegidas" (os dhimmi, judeus e cristãos), mas também por legítimo interesse na nova fé (FLETCHER, 1993, p. 35-40; WASSERSTEIN, 1985, p. 23).

Ser muçulmano tornou-se também parte da identidade ibérica e não apenas uma religião "dos invasores" como pretendeu a propaganda da chamada Reconquista. Já no século IX, Alvaro de Córdoba (Alvarus Paulus Cordubensis), um intelectual, teólogo e poeta cristão lamentava que a juventude de Al Andalus estivesse esquecendo o latim e que, em seu lugar, aprendesse o árabe. Ele dizia: "Os cristãos adoram ler os poemas e os romances árabes; estudam os teólogos e os filósofos árabes, não para refutá-los mas para aperfeiçoar com elegância seu domínio do idioma” (ALVARUS apud MENOCAL, 2004, p. 75). O que, sem dúvida, era uma realidade muito aceita em grande parte dos meios intelectuais da época, apesar das inevitáveis queixas saudosistas de personalidades como a do latinista Álvaro.

Emílio González Ferrín questiona que se possa definir Al Andalus como uma região de três culturas: islâmica, cristã e judaica. No seu entender, trata-se, na verdade, de "[...] uma cultura com três religiões, a do islã, a da cabala e a da noite escura da alma, como escreveria o imprescindível Borges" (GONZÁLEZ FERRÍN, 2006, p. 54). E ainda, segundo Ferrín:

Falamos de $\mathrm{Al}$ Andalus como cultura fronteiriça - limítrofe, as pessoas do limes, aluvião de tempo e história. De personalidades de fronteira. Em sua versão pós moderna 
falaríamos de interculturalidade, mas seguimos preferindo a forma mais clara e resumida de Cultura com maiúscula. $\mathrm{O}$ modo de reflexão com o qual se venha a ler tais passadiços culturais - como o andalus, que nos ocupa - deve consistir em tratar de forma humanista e enriquecedora a matéria das civilizações pretensamente enfrentadas e exemplificadas em pessoas, obras ou tempos fronteiriços concretos. O objetivo último é ampliar o conceito de Oriente e Ocidente de um modo - insistimos - intelectual. Afastado de versões e interpretações ilegítimas, folclóricas ou nacionalistas (GONZÁLEZ FERRÍN, 2006, p. 65).

Nessa perspectiva, caberia colocar, então, algumas questões: até onde $\mathrm{Al}$ Andalus é Ocidente? E de qual Ocidente estamos falando? Qual era ou quais eram as identidades de $\mathrm{Al}$ Andalus na Idade Média? É possível dizer que a fronteira entre Ocidente e Oriente ficava na Península Ibérica? Estaria certo falar de uma Espanha tripartida entre as três "religiões do livro" ou aquela foi uma cultura de amálgama, de enfrentamentos, de trocas, mas algo único e não um tempo de exceção na história ibérica, como muitos livros didáticos ainda mencionam? Em meu entender, o ponto de partida das pesquisas sobre o tema deveria considerar a Espanha medieval como detentora de uma cultura original e não um momento de tolerância, pois a própria palavra tolerância já é excludente e, de certa forma, aponta para as diferenças. Nesse sentido, as fontes da cultura material, da arte e da arquitetura, entre outras, constituem-se em documentos importantes para o historiador que se dedique ao estudo da Península Ibérica.

\section{A consolidação de Al Andalus e a difusão da arte e arquitetura mudéjar}

A sucessão do emir Abd-al-Rahmân se dá como em qualquer outro reino europeu, de forma hereditária até que, em 852, inicia-se um período de crises que vai desembocar na fragmentação do poder. Surgem das disputas entre pequenos reinos que ficarão conhecidos como taifas, palavra árabe que significa "facção" e que se origina da expressão árabe, corrente na época, que os designava como "reinos das facções". Ocorrem mudanças estruturais, mas Al Andalus permanece multirreligiosa, até que reste apenas Granada, último bastião muçulmano que só entregará o poder aos reis cristãos em 1492. 
Ao todo, foram 781 anos de presença do Islã na Espanha, o que está longe de ser um parêntesis ou apenas um enxerto na cultura cristã. Além disso, esse longo período não pode ser estudado como um simples transplante da cultura oriental para a Península Ibérica, pois se tratava de uma nova realidade social, de novas formas de relacionamento, com a prática de casamentos mistos e com largas parcelas da população, tanto de religião judaica quanto cristã, falando árabe.

$\mathrm{Na}$ análise da documentação da cultura material, um exemplo de grande relevância para o entendimento da Península Ibérica, durante a Idade Média, é a chamada arte e arquitetura mudéjar, extremamente rica em informações não apenas de caráter artístico, mas também no que diz respeito ao relacionamento entre as diversas comunidades em $\mathrm{Al}$ Andalus.

Apesar do sentido inicial da palavra mudéjar, que se refere aos muçulmanos que permaneceram na Espanha na medida em que os soberanos cristãos venciam as batalhas e tomavam o poder nas antigas taifas, ela é utilizada com maior frequência para designar um estilo arquitetônico e artístico também denominado de hispano-muçulmano.

No entanto, nem sempre os artesãos muçulmanos contratados pelos cristãos eram súditos dos pequenos reinos cristãos na Península. Denomina-se também mudéjar o trabalho realizado pelos muçulmanos que viviam no reino independente de Granada e eram contratados por senhores cristãos de outras regiões. Viajavam, então, para terras cristianizadas para trabalhar nas obras que lhes eram encomendadas, executavam seus trabalhos e depois retornavam a Granada, que só caiu em 1492. Esse trânsito foi frequente e os monumentos na Espanha até hoje documentam sua existência e fecundidade.

Para deixar clara a conceituação desse tema é interessante lembrar aqui o fato de que existe uma discussão acerca do sentido das palavras mudéjar e mourisco, algumas vezes utilizadas como sinônimos. Gonzalo M. B. Gualís, especialista em mudejarismo, destaca que, embora alguns autores utilizem "mourisco" para a arte e arquitetura dos muçulmanos convertidos à força, ele próprio prefere denominar de mudéjar todas as manifestações artísticas que apresentem características 
hispano-muçulmanas, já que as conversões foram ocorrendo de maneira desigual e em datas muito distintas, com poucas estatísticas confiáveis (BORRÁS GUALÍs, 1990, p. 41). Além disso, pode-se acrescentar que, na Idade Média, a autoria exata das obras é de difícil obtenção, sendo preferível, portanto, uma análise que leve em conta as diversas características do objeto estudado, seu estilo, bem como as eventuais informações de fontes escritas que tenham se preservado.

É possível, assim, afirmar que, por um lado, a arte e a arquitetura mudéjar se constituem em uma especificidade ibérica e não no simples transplante de criações orientais para o Ocidente, pois resulta em uma fusão multicultural que alcança uma identidade própria nas mãos de artesãos muçulmanos integrados na sociedade ibérica. As técnicas e soluções encontradas por eles adaptavam-se às características físicas e sociais do meio para o qual produziam. Por outro lado, as criações mudéjares se disseminaram pelo fato de que a nobreza cristã não desejava abrir mão da alta qualidade da mão de obra dos muçulmanos, aliada às características extremamente funcionais de seus projetos, perfeitamente adaptados ao clima da Península Ibérica.

Inúmeros são os exemplos até hoje presentes em território hispânico e entre os mais bem preservados estão o Claustro do Mosteiro de Guadalupe, em Cáceres, o Alcázar de Sevilha, diversas construções, principalmente igrejas, na província de Teruel, a Catedral de Zaragoza e parte do Palácio da Aljafería, dessa mesma cidade. No caso da Aljafería, mesmo tendo sido inicialmente um palácio muçulmano de imenso prestígio, ela foi posteriormente remodelada pelos reis de Aragão, que contrataram artesãos mudéjares para o trabalho e, mais adiante, recebeu acréscimos importantes de Fernando e Isabel. O conjunto se manteve magnífico, de grande refinamento, contendo elementos árabes e europeus em perfeita fusão e total adaptação ao clima ibérico.

A Aljafería foi construída inicialmente na segunda metade do século XI para ser a residência de Abû Ja’ar e passa para as mãos de Alfonso de Aragão em 1118. Nos pátios da parte muçulmana do palácio, é possível observar os arcos entrelaçados, característicos do período dos reinos "taifas" (ver Figura 2). Esses arcos entrecruzados, de grande riqueza decorativa e exuberância, são típicos de 
um período em que diversos reinos muçulmanos concorriam entre si por prestígio e riqueza. Não há dúvida que Abû Ja'far pretendeu mostrar, na arquitetura do palácio, o esplendor de sua corte, famosa por receber artistas e intelectuais das mais diversas procedências (LAFUENTE, 1998, p. 63-85). E é certo também que os conquistadores cristãos que tomaram Zaragoza não fizeram restrições ao se apropriar da arquitetura e da arte de origem islâmica dos conquistados, o que, aliás, ocorreu também em outras taifas que passaram para as mãos de soberanos cristãos.

Figura 2 - Palácio da Aljafería ${ }^{6}$

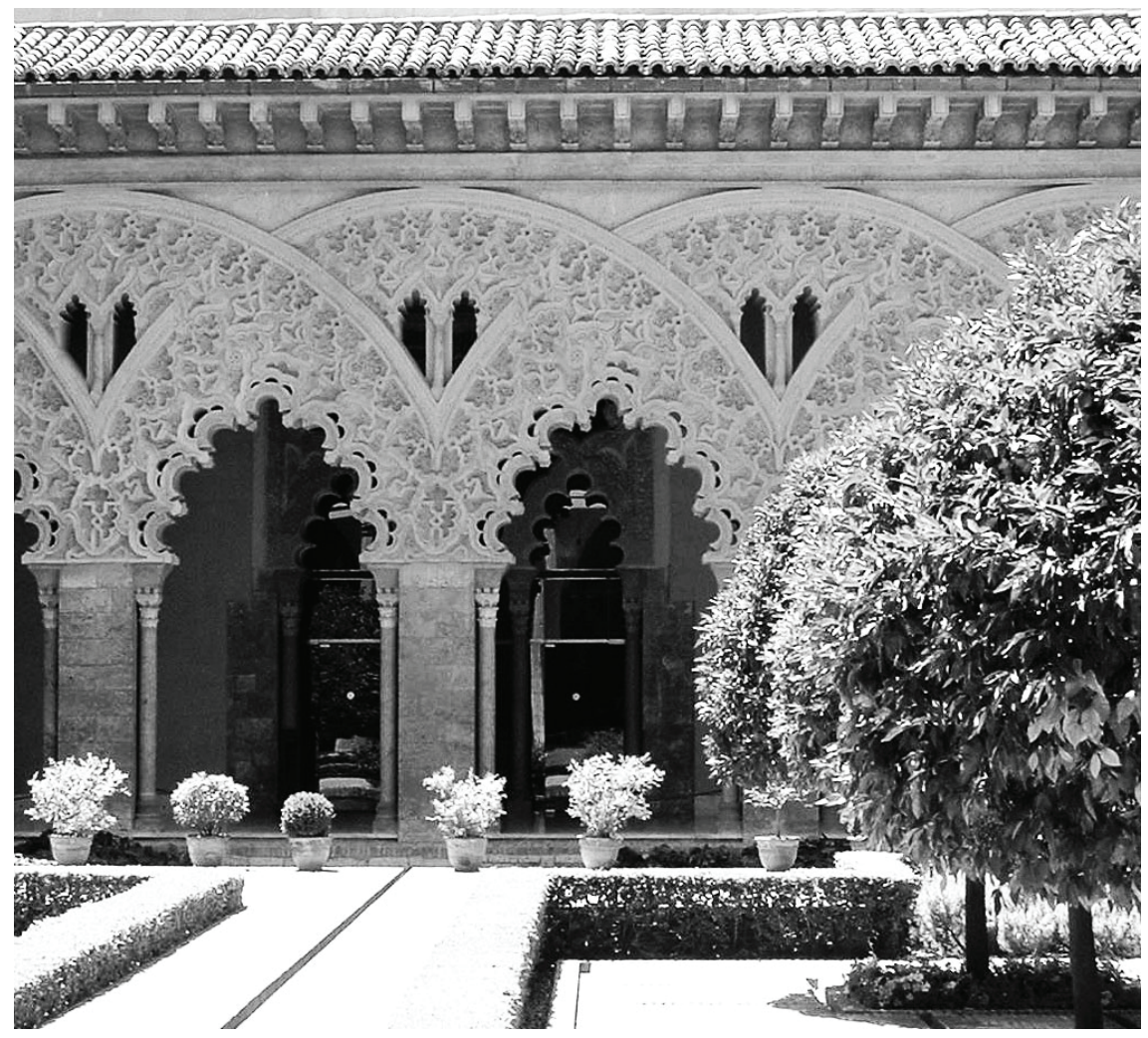

\footnotetext{
${ }^{6}$ Foto feita pela autora do artigo.
} 
Muitos dos acréscimos que os soberanos cristãos fizeram ao Palácio da Aljafería foram sendo realizados no decorrer de vários anos e, em 1492, Fernando e Isabel também foram responsáveis por novas construções, mantendo em diversas partes do palácio a arquitetura muçulmana e também o estilo mudéjar que tinha sido acrescentado por monarcas cristãos que os antecederam (ver Figura 3).

Apesar de serem raras as atribuições de autoria de artistas e artesãos na época, o "mestre" mudéjar Faraig de Gali é apontado como tendo sido encarregado de dirigir os trabalhos encomendados pelos Reis Católicos para os aposentos que ocupariam dentro do complexo da Aljafería.?

Figura 3 - Construção mudéjar na Aljafería ${ }^{8}$

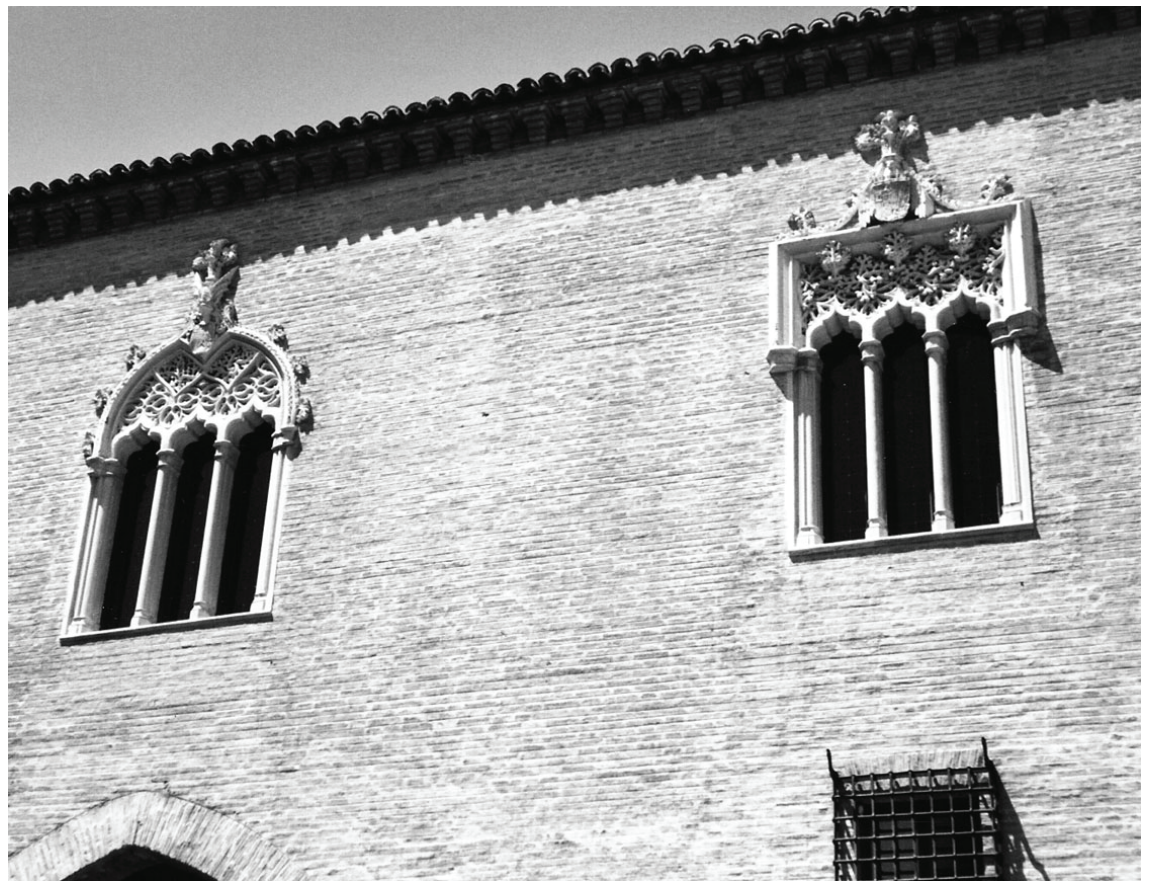

7 Informação obtida em visita ao Palácio da Aljafería em julho de 2005.

8 Foto feita pela autora do artigo. 
Não é, porém, apenas a elite cristã que contrata mão de obra muçulmana e adota o estilo de construção com influência islâmica. Alguns judeus seguem o mesmo caminho e, entre outras obras, destaca-se a sinagoga mudéjar de Toledo que posteriormente foi transformada em igreja e, atualmente, é conhecida pelo nome curioso de "Sinagoga” (sic) Santa María La Blanca.

Embora não caiba aqui uma discussão mais aprofundada sobre os estilos artístico-arquitetônicos que caracterizaram a cultura ibérica medieval, tais considerações reforçam a ideia central da obra de Gonzalez Ferrín, à qual já me referi acerca da especificidade de uma cultura que se desenvolveu com características próprias e marcou profundamente a Península Ibérica. Ferrín destaca a originalidade de $\mathrm{Al}$ Andalus e sua diferença do resto da Europa, diferença essa que, em meu entender, foi percebida até o século XV, mas depois, pouco a pouco, apagada em nome da ideologia de uma Europa uniformemente cristã.

\section{As relações de vassalagem em Al Andalus}

A essas considerações poderíamos acrescentar, para uma análise da especificidade de Al Andalus, o fato de que, muitas vezes, as disputas internas não eram necessariamente religiosas e sim de caráter político, como as que ocorriam no resto da Europa. Os soberanos das taifas muçulmanas se valiam, em inúmeras oportunidades, do apoio de senhores cristãos e vice-versa, com o intuito de derrotar os inimigos que ameaçavam seu poder. Um dos casos mais conhecidos é o de Muhammad ibn Yûsuf ibn Nasr que, após uma série de conquistas, estabeleceu-se, em 1237, em Granada, inaugurando a dinastia dos Nazaris ou Násridas. Muhammad ibn Nasr não apenas aceitou Fernando III de Castela, rei cristão, como soberano de parte de Al Andalus, mas ainda lhe deu apoio efetivo na guerra contra a taifa muçulmana de Sevilha (BARRUCAND; BEDNORZ, 2002, p. 179).

Não foram poucas também as situações nas quais cavaleiros cristãos prestaram vassalagem a senhores muçulmanos e Don Rodrigo Dias de Vivar, o conhecido El Cid, é um exemplo emblemático de como as relações entre muçulmanos e cristãos na Espanha Medieval estavam muito mais próximas do padrão de relacio- 
namento presente em outros reinos e feudos europeus do que de uma situação de puro e simples enfrentamento religioso.

A antiga imagem romântica de El Cid certamente não se sustenta mais, pois já é bem sabido, por meio de pesquisas históricas que, entre 1081 e 1086, o cavaleiro Rodrigo Díaz, originário de Vivar, que tinha sido vassalo do rei Alfonso VI de Castela, após romper com o soberano passou a lutar a favor da corte muçulmana de Zaragoza (FLETCHER, 2002, p. 180-187).

O vai-e-vem de alianças foi uma constante na Espanha Medieval, como, aliás, em toda a Europa. A História Ibérica não foi, na Idade Média, um afrontamento único de cristãos contra muçulmanos, como pretenderam os relatos tradicionais da Reconquista.

\section{Conclusão}

Ainda são raros os historiadores que se debruçam sobre novas interpretações da sociedade multirreligiosa da Península Ibérica sem tratá-la como algo fora da norma do contexto europeu. A maioria das obras ainda deixa entrever que o cristianismo era a religião predominante na região e que teria havido uma unidade, rompida durante alguns séculos, entre o antigo reino visigodo e a Espanha cristã, unificada a partir do século XV. Ora, os cristãos que participaram da chamada Reconquista pouco tinham em comum com os visigodos e deles divergiam inclusive nos ritos. $\mathrm{O}$ mundo visigodo entrou em decadência muito antes das invasões muçulmanas que apenas deram o golpe final em um governo já totalmente desestruturado e sem apoio de sua população.

Como vimos, as lutas entre os poderes em Al Andalus se assemelhavam às disputas feudais de sua época e não era incomum que soberanos muçulmanos e cristãos se aliassem, de acordo com as circunstâncias, com a fé religiosa, tendo pouca ou nenhuma participação em muitas das guerras do período dos reinos taifas. A história oficial - ainda hoje largamente repetida no Brasil - apresenta os sete séculos e meio de presença muçulmana na Espanha como um período de exceção, 
eventualmente de convivência pacífica, de tolerância ou de intercâmbio cultural entre o Ocidente e o Oriente, mas raramente como o que ele realmente foi: uma parte inteira da História da Espanha, uma cultura amalgamada de influências múltiplas, que está presente no idioma, na literatura, nas artes, nos hábitos, enfim, no conjunto da identidade ibérica.

\section{Musulmans et Chrétiens d'Al-Andalous: une identité au-delà du clivage entre Orient et Occident}

\section{Résumé}

Cet article étudie des aspects d'Al-Andalous, c'est-à-dire de l'Espagne dans la période pendant laquelle elle a été en grande partie sous la domination musulmane, et particulièrement la question de son identité. Plutôt qu'une rencontre de cultures mutuellement "tolérées », Al-Andalous était une société unitaire dont les caractéristiques ne doivent pas être considérées comme une parenthèse dans l'histoire d'Occident mais bien comme partie intégrale de lêtre hispanique. Même si les juifs aient participé de la formation culturelle d'Al-Andalous, le regard de cette recherche se dirige plutôt vers la relation entre musulmans et chrétiens, puisque celle-ci comprend des questions relatives à l'exercice du pouvoir politique et aux objets publics de la culture matérielle, aspects où la participation du judaïsme sépharade a été moindre, ce dernier sétant distingué surtout dans la philosophie.

Mots-clés: Al-Andalous. Identité. Hispanomusulmans.

\section{Referências}

BARRUCAND, Marianne; BEDNORZ, Achim. Arquitectura islámica en Andalucía. Colonia: Taschen, 2002.

BATTÛTA, Ibn. Voyages: III: Inde, Extrême-Orient, Espagne et Soudan. Paris: Maspéro, 1982. 
BIBLIOTHÈQUE NATIONALE DE FRANCE. Indes merveilleuses: l'ouverture du monde au XVe siècle. Paris: Bibliothèque Nationale de France. Chancellerie des Universités, 1993.

BORRÁS GUALÍS, Gonzalo M. El arte mudéjar. Teruel: Instituto de Estudios Turolenses, 1990. (Serie Estudios Mudéjares).

ETTINGHAUSEN, Richard; GRABAR, Oleg. The art and architecture of Islam: 650-1250. New Haven: Yale University, 1994.

FLETCHER, Richard. Em busca de El Cid. São Paulo: Unesp, 2002.

FLETCHER, Richard. Moorish Spain. Berkeley: University of California, 1993.

GONZÁLEZ FERRÍN, Emilio. Historia general de Al Ándalus: Europa entre Oriente y Occidente. Sevilha: Almuzara, 2006.

HATTSTEIN, Markus; DELIUS, Peter (Ed.). Islam: arte y arquitectura. Berlim: H. F. Ullmann, 2004.

HOURANI, Albert. Uma história dos povos árabes. São Paulo: Companhia das Letras, 1994.

LAFUENTE, José Luis Corral. Historia de Zaragoza: Zaragoza musulmana (7141118). Zaragoza: Ayuntamiento de Zaragoza, 1998, p. 714-1118.

MENOCAL, María Rosa. O ornamento do mundo. São Paulo: Record, 2004.

PALAZZO, Carmen Lícia. A cultura material na Rota da Seda: fontes para pesquisa em História Medieval. Aedos, Porto Alegre, v. 2, n. 2, p. 464-470, 2009.

ROBINSON, Francis (Ed.). The Cambridge llustrated History of the Islamic World. Cambridge: Cambridge University, 1996.

VERDON, Jean. Voyager au Moyen Age. Paris: Perrin, 1998.

WASSERSTEIN, D. The Rise and the Fall of the Party-Kings: politics and Society in Islamic Spain, 1002-1086. Princeton: Princeton University, 1985. 


\section{Para publicar na revista Universitas Humanas, acesse 0 endereço eletrônico www.publicacoesacademicas.uniceub.br. Observe as normas de publicação, para facilitar e agilizar o trabalho de edição.}

